Issue 1/2018

\title{
ANALYSIS OF FOOD PRODUCTION AND POVERTY REDUCTION OF BANGLADESH
}

\author{
Haradhan Kumar MOHAJAN ${ }^{1}$ \\ ${ }^{1}$ Premier University, Chittagong, Bangladesh \\ Email: haradhan1971@gmail.com
}

\begin{abstract}
This study aims to investigate the food production and poverty reduction of Bangladesh in brief. Although the country faces various problems for the economic progress since the independent in 1971, in the last forty-eight years, the increase of food production and poverty reduction of the country became remarkably. Bangladesh is a densely populated developing country in the southern Asia. The Government of Bangladesh is trying efficiently to reduce poverty of the country. In Bangladesh, about 20\% of the populations still live below the poverty line, heavily undernourished with inadequate access to safe and nutritious food for a healthy life. The data of the study were collected through the secondary sources of the country. In Bangladesh, during 2000 to 2005, income poverty reduced from 48.9\% to 40.0\%, 2010 to 2016 reduced from $31.50 \%$ to $20 \%$, and in 2018 it is expected to be reduce to $16 \%$. An attempt has been taken here to show the ways to increase more food production and poverty reduction of the country.
\end{abstract}

Keywords: food; poverty reduction; inflation; GDP; subsidies in food; economic development.

JEL Classification: $\mathrm{Q}_{18}$

\section{Introduction}

People's Republic of Bangladesh is a densely populated developing country in the southern Asia and its area is $147,872 \mathrm{~km}^{2}$. It is a unitary parliamentary democratic country, and its legislature is Jatiya Sangsad. Its current constitution is formed at 4 November 1972. Dhaka is the capital city of the country. It is a Muslim dominated country. In 2004, Muslim was about $89.5 \%$, Hindu was about $9.6 \%$, other was $0.9 \%$. In 2018, its populations become more than 160 millions. About 70\% of the populations 


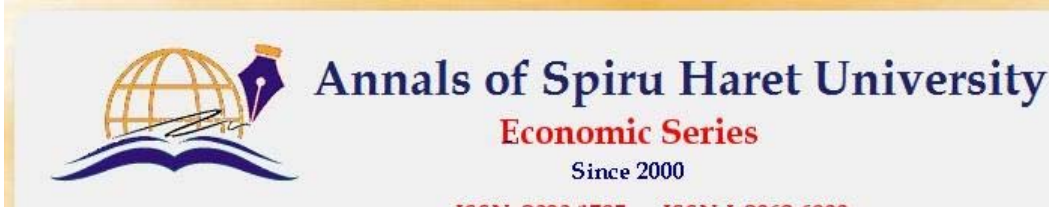

ISSN: 2393-1795 ISSN-L:2068-6900

\section{Issue 1/2018}

live in the rural areas. Agriculture is the main source of income; about $80 \%$ of the populations are involved with this sector [Mohajan, 2013a; Bangladesh Country Profile, 2018].

All the living organisms need food to survive. Food and nutrition are basic rights of human beings. After food and shelter, people want to develop their economic conditions. Food security is the main problem of every Government of Bangladesh (GoB) [Food and Agriculture Organization, FAO, 2000].

Food for all the citizens is a basic right asserted by the National Constitution of Bangladesh. In Bangladesh, the sufficient production, distribution, and availability of essential food items have always been a cause for anxiety for successive Governments, international donor organizations, and socio-economic researchers. Rice is the staple food of Bangladesh, and among 94\% of all food grains produced annually is rice. About $40 \%$ of the total national employment and $48 \%$ of rural employment is generated from the rice sector. The rural development is an essential prerequisite for the formulation and implementation of an effective strategy for increasing food security, reducing poverty, and promoting overall economic growth [Country Profile, 2018].

Food security is a main target of the GoB. The Government also imposes subsidies in food, agriculture, and agricultural materials to improve the food production. However, these attempts will not provide permanent solution to food security, and economic development of the citizens [Mohajan, 2013b].

Bangladesh can reasonably desire to become a middle-income country by 2020, which require a sustained 7.5\% annual gross domestic product (GDP) growth or more. To achieve this, Bangladesh will need a series of structural changes to ensure a more rapid, sustained, and employment-generating growth. Bangladesh is also one of the most vulnerable countries to weather variability and natural disasters [World Bank, 2007].

According to the Household Income Expenditure Survey (HIES) the calorie intake decreased to 2,238.5 Kcal/capita/day in 2005 from 2,263 Kcal/capita/day in 2000; whereas cereals, which are one of the main source of calorie intake, decreased to 469.2 $\mathrm{gm} / \mathrm{capita} /$ day from $486.7 \mathrm{gm} / \mathrm{capita} /$ day [Bangladesh Bureau of Statistics, BBS, 2005]. The present Government has targeted to reduce poverty rate to $15 \%$ by 2021.

\section{Literature review}

Mir Khaled Iqbal Chowdhury, Sherin Fatima Rumi, and Md. Mushfiqur Rahman have stressed on the increase of the production of Boro rice in Bangladesh to achieve self-sufficiency of food-grain production [Chowdhury et al., 2013]. Dayal Talukder and Love Chile have examined the characteristics of rice 192 


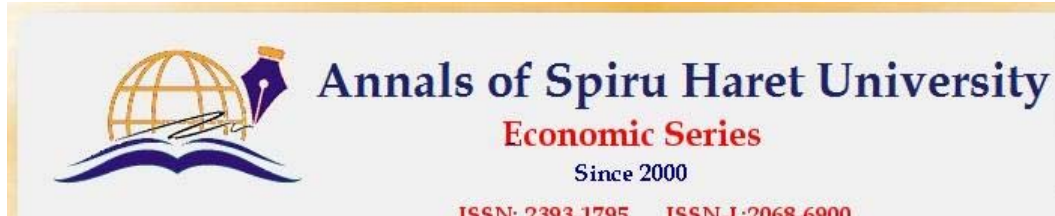

ISSN: 2393-1795 ISSN-I-2068-6900

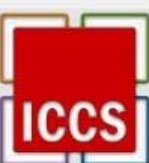

Issue 1/2018

cultivation and rural rice market in the post-trade-liberalization era [Talukder \& Chile, 2015]. Md. Zohurul Islam, Ratna Begum, Sajia Sharmin, and Akteruzzman Khan have analyzed the profitability, constraints and factors that affect rice production in coastal area of Bangladesh. They have used Cobb-Douglas production function in their study [Islam et al., 2017]. Abeda Sultana has tried to find the problems and prospects of rice marketing in Bangladesh. She has shown that there is a comparative advantage in the production of high yielding rice in Bangladesh, but its marketing system is not suitable to the small farmers to bring fair price. She has identified that the major causes of food price hike are natural disaster, inadequate supply of food grain in the market, less production, hoarding by traders and creating artificial food crisis in the market, problems of communication system, and increase of intermediaries in the market to reach food grain to consumers [Sultana, 2012].

Susmita Dasgupta, Md. Moqbul Hossain, Mainul Huq, and David Wheeler have used econometric analysis to predict the impact of climate induced increases in soil salinity on high yielding variety rice production in coastal area of Bangladesh [Dasgupta et al., 2017]. Marites Tiongco and Mahabub Hossain have investigated the relationship between adoption of modern rice varieties and rice varietal diversity on household farms in Bangladesh [Tiongco \& Hossain, 2015]. A. H. M. Monzurul Mamun, Bikash Chandra Ghosh, and S. M. Rayhanul Islam have examined the trend of three main climatic variables; temperature, rainfall, and relative humidity, for Rajshahi, Bangladesh by using the time series data for the 1972-2010 period, and assesses the relationship between the variables, and the yield of three major rice crops; Aus, Aman, and Boro [Mamun et al., 2015].

Rahman et al. [2016] have forecasted on area and production of Aus rice in Bangladesh. They have used Box-Jenkins Autoregressive Integrated Moving Average (ARIMA) time-series methodology to predict this. Jayanta Kumar Basak, M. Ashraf Ali, Md. Nazrul Islam, and Md. Abdur Rashid have discussed the effect of climate change on yield of two varieties of Boro rice has been assessed using the DSSAT modeling system. They have provided results of BR3 and BR14 Boro varieties for the years 2008, 2030, 2050, and 2070 for 12 districts of Bangladesh [Basak et al., 2010]. Udaya Sekhar Nagothu, Attila Nemes, Jatish Chandra Biswas, and Motaleb H. Sarker have contributed to the development of an integrated adaptation framework in order to sustain and improve rice production under different climate change scenarios in Bangladesh [Nagothu et al., 2014]. Kamala Gurung, Humnath Bhandari, and Thelma Paris have examined the transformation from rice farming to commercial aquaculture, and its implications for gender roles 


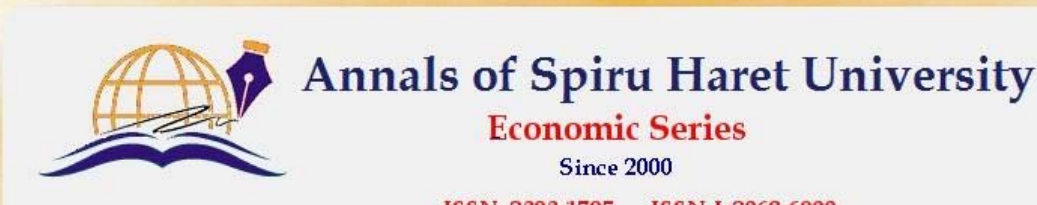

ISSN: 2393-1795 ISSN-L-2068-6900

\section{Issue 1/2018}

and relations, women's access to and control over resources, household food security, and livelihood. They have collected primary data from 400 sample households located across 10 villages in northern and southern parts of Bangladesh [Gurung et al., 2016]. Elena Gurgu and Raluca Zorzoliu have highlighted Romania's role in the current international economic context. They have analyzed the state of the Romanian economy referring to its main macroeconomic indicators and have proposed ways, and measures to revive the economy of Romania [Gurgu \& Zorzoliu, 2016]. Doina Dascalu has analyzed the public debt, in terms of sustainability and vulnerability indicators, under a functioning market economy. She has indicated that in order to achieve sustainable levels of public debt, the European Union Member States are required to establish and accomplish medium term strategic budgetary goals to ensure a downward trend in public debt [Dascalu, 2016].

\section{Objectives of the study}

This study heartily wishes to focus on the food insecurity and poverty reduction of Bangladesh. Therefore, we have emphasized on the food sector of the country. This study will be carried out under the following specific objectives:

- to study the impacts of the people during the abnormal food price hike;

- to study the effect of poverty and economic situation of food price inflation;

- to know the role of Government and social conscious people to increase food production and modernization of the agriculture sector.

\section{Methodology of the study}

The data were collected to achieve the result for the purpose and scope of this study. In this study, secondary data are used to enrich the article. The secondary data are collected through different sources such as: journals, newspapers, magazines, thesis, census reports, addresses delivered by Government officials, press releases, seminars, conferences, NGOs reports, and electronic resources.

\section{Food security in Bangladesh}

In Bangladesh, consumption of only rice is about $400 \mathrm{gm} / \mathrm{capita}$ /day. Wheat is the second food grain, followed by maize, which is in the third position. In 1970s, about $70 \%$ people of Bangladesh were below the poverty line in relation to food consumption, and at present it has come down to $20 \%$ in 2016, but still it is far from 

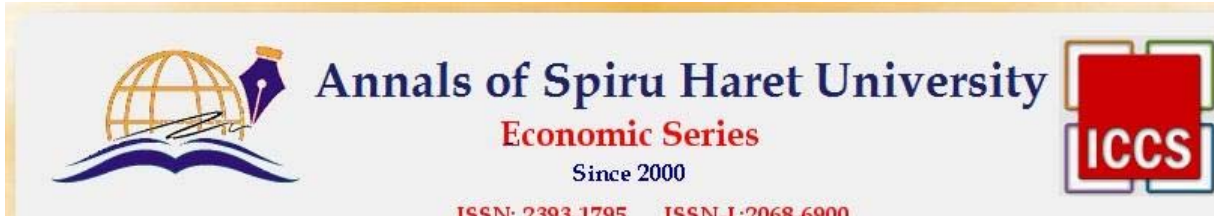

ISSN: $2393-1795$ ISSN-I.2068-6900

Issue 1/2018

being food secure. More than half of the children of Bangladesh are underweight, which is obviously the signal of malnutrition of the future generation. According to the latest Household Income and Expenditure Survey 2010 [HIES, 2016], about onefifth people of Bangladesh are living below the national poverty line. Population of Bangladesh below the poverty line in 2008, 2010, and 2016 were, respectively, 36.3, 31.51, and 20\% [Country Profile, 2016].

The rise of food price has a severe impact over the marginalized people. The prices of rice in Bangladesh were highly volatile between 2003 and 2009, and the gross income of the poor decreased by $36.7 \%$ due to surge of food items. In Bangladesh, food prices are increased by $72 \%$ over a period of only 10 months from June 2007 to April 2008 at the backdrop of global food prices hike. This rising inflation has become an alarming threat to the poor and middle class people from all segments of the society. According to the World Bank, about 4 million people of Bangladesh have been pushed below the poverty line due to abnormal rise in food prices [Mohajan, 2013b].

In Bangladesh, $70 \%$ of total population live in the rural areas and $80 \%$ of these villagers are directly related to agriculture. The sector employs about $51 \%$ of the total labour force of the country, and provides over $90 \%$ of the rural employment [BBS, 2004]. Food grain production in 2005 was 27.26 million metric ton (mMT), in the FY 2006-07 was 28.05 mMT, in the FY 2007-08 was 29.54 mMT [Ahmed et al., 2009].

Over the past three decades, rapid expansion of green revolution technologies, irrigation in dry season, Government subsidies in agriculture, improved seeds, increase of arable land, appropriate pesticides use, and sufficient fertilizer use have led to a rapid increase in rice and wheat production in Bangladesh [Mohajan, 2013a].

\section{Effects of food price inflation}

The food price inflation has a severe impact over the marginalized people of Bangladesh. Food inflation leaves a harmful impact on the purchasing power when the per capita GDP does not correspond with inflation. The International Monetary Fund (IMF) warned Bangladesh that excess liquidity and resurgent international commodity and food prices might push inflation to double-digit levels by year-end of 2009 [The Daily Star, 30 October 2009]. Bangladesh has already experienced a double-digit food inflation rate on point-to-point basis since July 2007.

Rice is the staple food of Bangladesh, and wheat is in the second position. Change in prices of two food stuffs affects the people most adversely than changes in prices of any other commodity. Persistent high inflation may unleash forces that 

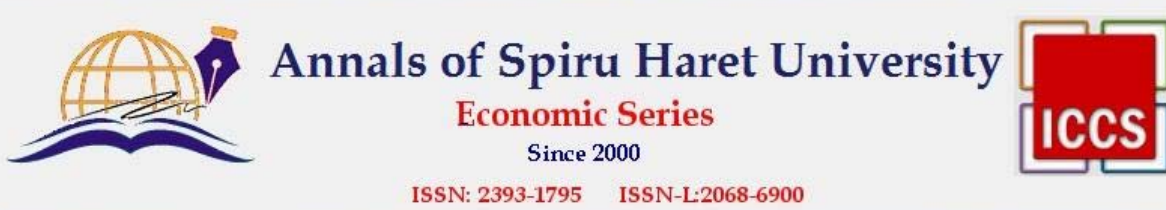

\section{Issue 1/2018}

jeopardize macroeconomic stability and economic growth. Between September 2009 and September 2010, the nominal rice and wheat prices increased by 63\%, and 33\%, respectively. The corresponding real prices also have risen by $53 \%$ and $24 \%$, with a substantial rate of increase in rice prices [Bangladesh Economic Update, 2011]. In Bangladesh, food prices continued to increase and drove up the overall inflation rate in FY 2010-11. At the end of 2017 and in the beginning of 2018, the price of rice has increased record due to irregular flood. In 2017 and 2018, more than one million Rohinga Muslim refugees took shelter in Bangladesh from Myanmar due to nonhumanitarian oppression of the army and civilians of that country. The GoB is providing food, clothes, treatment, and shelter to these helpless people. These additional one million people became burden to the economy of the country [Country Profile, 2018].

The inflation in June 2011 was 10.2\% compared to 8.7\% in June 2010, and food inflation rate was higher than the general inflation rate. In 2012, inflation has reached to about $10.92 \%$. Higher inflation in the country is due to rising commodity prices in the world market, and for the higher spending than the budget of the Government. The inflationary remain unchanged despite a bumper production of rice, potato, fruits, and vegetables due to the borrowing of the Government from the banks [Country Profile, 2013].

During the last quarter of the year 2010, the average global food price index increased by $2.93 \%$, whereas the average local food price of Bangladesh increased by $0.70 \%$, and the general inflation increased by $0.53 \%$. General, food and nonfood inflation rates in Bangladesh during FY 2005 to FY 2011 are given in table 1.

Table no. 1. General, food and non-food inflation rates in Bangladesh during FY 2005 to FY 2011

\begin{tabular}{|c|c|c|c|}
\hline Year & General inflation rate (\%) & Food inflation rate (\%) & Non-food inflation rate (\%) \\
\hline 2005 & 6.48 & 7.91 & 4.33 \\
\hline 2006 & 7.16 & 7.76 & 6.4 \\
\hline 2007 & 7.2 & 8.11 & 5.9 \\
\hline 2008 & 10.06 & 11.43 & 7.35 \\
\hline 2009 & 5.51 & 7.9 & 4.2 \\
\hline 2010 & 7.52 & 9.9 & 3.9 \\
\hline 2011 & 9.76 & 13.9 & 4.32 \\
\hline
\end{tabular}




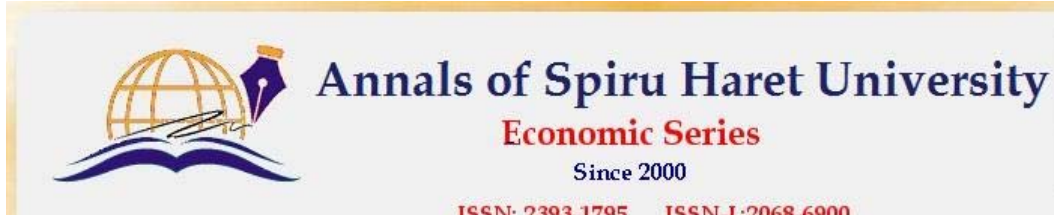

ISSN: 2393-1795 ISSN-I*2068-6900

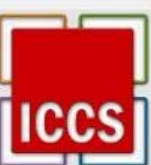

Issue 1/2018

The continued increase in food prices has been suggested due to the global crisis, and to the increasing political and economic instability; particularly in the underdeveloped and developing countries. The price that drastically increased in 2007 had faced a downward trend after June 2008, but from 2009, the price has started to rise again [Bangladesh Economic Update, 2011].

\section{Food and nutritional scenario}

In Bangladesh, food production data are collected by BBS, Bangladesh Rice Research Institute (BRRI), Bangladesh Agricultural Research Institute (BARI), Department of Agriculture Extension (DAE), Ministry of Food and Ministry of Agriculture on a regular basis. BBS is the only authorized body under Government structure to publish production data. According to their collected data, in the last decade, the production of rice has increased, vegetable production becomes almost doubled, potato production increases 2.5 fold, fish production has increased due to increase in inland fishery, meat production has increased, superseding the rate of increase in population, egg, and milk production also increased in parallel. On the other hand, total production of pulses (one of the major sources of protein for the poor), oilseeds and fruits has gone down. The market demand on pulses, edible oils, fruits, and spices are fulfilled mainly by the import. The net production availability of sweeteners and spices remained almost unchanged during the last decade. However, the country still is deficient in production of all the non-cereal food items to provide balanced food for all. Meat and fishes are imported for the fulfilment of protein deficiency [Mohajan, 2013b].

During the independence in 1971, Aman was the major food crop, which was the dominant source of total rice production. Structure of rice production in Bangladesh has remarkably changed over time. In 2013, Aman rice occupies 50\% of total rice area and contributes $38 \%$ of total production, Boro contributes about $41 \%$ of total rice area and contributes $56 \%$ of total rice production in Bangladesh, and Aus rice supplies about $9 \%$ of total rice area and $6 \%$ of rice production [Mohajan, 2013b].

The development of cultivation system, inclusion of non-cultivable land in cultivation, increased production of rice thrice in a year, invention of new variety of species and expansion of irrigation system, increased the production of rice over time [BBS, 2013].

In Bangladesh, there are three types of poor, as follows [Khuda, 2011]:

- The chronic poor; those who are poor even during good times, because they have limited access to assets and income to manage risks, and even small reductions in their assets and income can have serious adverse consequences for them. 

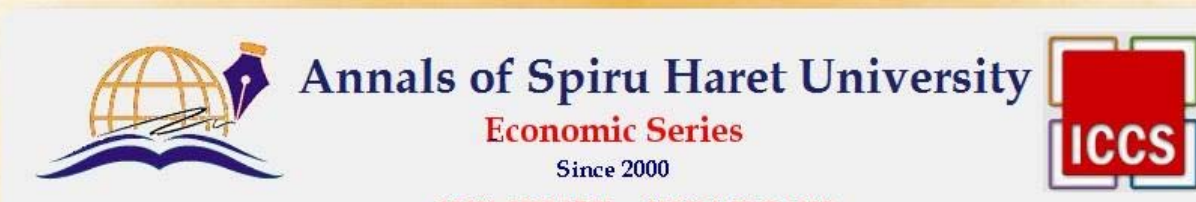

ISSN: 2393-1795 ISSN-L:2068-6900

Issue 1/2018

- The transient poor; those who live close to the poverty line and could fall into poverty when an earning individual household dies or the economy as a whole faces hardships.

- Other vulnerable population; the groups for whom general stability and prosperity alone would not be sufficient, such as, the disabled and divorced/ separated/widowed women without access to any regular employment or find no help of others.

Bangladesh has obtained food through domestic production, imports, and food aid. In Bangladesh, the first two sources have increased, but the third has decreased [GoB, 2005]. In 2016, the GoB demanded the country to be selfdependent in food production, and export rice [Country Profile, 2016]. The poverty of Bangladesh is not decreasing readily due to low income of most of the populations, recurrent natural calamities, increase of population, and increasing international prices of food commodities. The cereal food production (including maize) was 27.35 mMTs in 2004-05. Unfortunately, food aid declines from about 600,000 MT in 1990s to about 300,000 MT in 2004 [BBS, 2005].

\section{Access to food in Bangladesh}

Food access is correlated with food availability. Per capita food availability is actually higher than the per capita food intake. In recent years, the rapidly increasing food price has made it difficult for the poor, low, and middle income group to have access to food. In 2005, per capita food intake came down to $469.2 \mathrm{gm} / \mathrm{capita} /$ day from $486.7 \mathrm{gm} / \mathrm{capita} /$ day in 2000 , over the same period food inflation increased to $7.91 \%$ from $1.38 \%$. During the food price hike, the burden increases for the lower income groups as these groups spend a larger share of their budget on food. The individuals who have irregular income from daily wage labour and lacking productive assets, such as day labourers, fishermen, vendors and beggars, cannot access food perfectly. The children, disabled, and pregnant and lactating women face the greatest nutritional risk during the food price increase [Ahmed et al., 2009].

\section{Victims of food price hike}

The poorest citizens were adversely affected during the food price soar, because the share of food expenditure is the highest for them. The conditions of the poor of Bangladesh during the food price inflation are as follows [Mohajan, 2013b]:

- Day labourers, female-headed households, especially widow/divorced, separated/abandoned females; people with fixed and low income, large families with few earning members or only one earning member, small and marginalized 198 


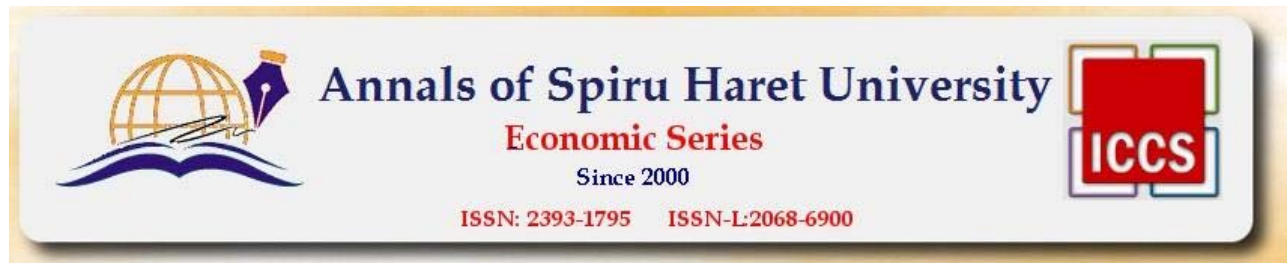

Issue 1/2018

farmers who are net buyers of staple, small job holders in urban areas, and selfemployed marginal people are severely affected due to the increase of food price.

- Extremely poor people who live in urban slums areas, such as small shop owners, vendors on footpaths, beggars, and garment workers suffer severely during the food price hike. On the other hand, some people of slum areas, such as rickshaw and van pullers, CNG (compressed natural gas) taxi and cab drivers, did not suffer much; as they charged people higher than usual, and earn more to face the food price hike efficiently.

- During the food price increase some non-social activities and crimes, such as sex working, begging, smuggling, petty theft, drug trafficking, etc., increase in the society.

- Sometimes children, women, and even elderly people are engaged in force work to mitigate hunger.

- In most families from the urban areas, the acquisition of beef, mutton, chicken, milk and milk products, fish, dry fish, and lentil has reduced, because they have to spend half or more than half of their household incomes to buy food grains in order to survive starvation, and are compelled to avoid these costly food items. As a result, these families suffer from malnutrition in the long term.

- Food price hike also affects the lower middle class families, because they cannot spend more for food; as their income is limited, and they cannot start begging due to their social status. They did not find loan from any source to face the economic crisis. Government or NGOs provide them no aid, as they are not extremely poor. Some of them have wealthy relatives, but in most cases, they are completely ignored by their rich relatives. Sometimes, they are compelled to sell their only assets, such as farmland, livestock, rickshaw-vans, etc. Their schooling children have to start labour. Eventually, they become extremely poor, and cannot escape from the poverty cycle.

Four areas in Bangladesh are identified as most vulnerable during the food price hike. These are, Monga (the north-west part), Haor (the north-central part and parts of the north-east), coastal river erosion (south), and the Chittagong Hill Tracts (south-east). Monga prone districts are Kurigram, Lalmonirhat, Nilphamari, Rangpur, Gaibandha, Bogra, and Serajganj. The typical characteristics of the food insecurity prone districts are as follows [Ahmed et al., 2009]:

- Crops are in the field waiting to be harvested having no employments in the agricultural fields. 

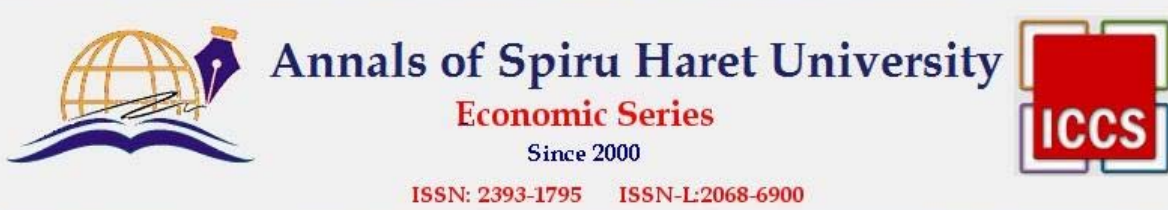

Issue 1/2018

- The household level food stock is mostly consumed amid inadequate supply of food grain in the market.

- The price of rice in the market is very high, while the marginal farmers and the labourers run out of food and cash.

\section{Poverty reduction in Bangladesh}

In Bangladesh, during 2000 to 2005, income poverty reduced from $48.9 \%$ to 40.0\% [Bangladesh Economic Review, BER, 2008], 2005 to 2010 reduced from $40 \%$ to $31.50 \%$ [HIES, 2010], and 2010 to 2016 reduced from $31.50 \%$ to $20 \%$ [Country Profile, 2016]. The present Government has targeted to reduce poverty rate to $15 \%$ by 2021 . The incident of poverty, using Cost of Basic Needs (CBN) method, at national level, declined from $58.50 \%$ in 1983 to $48.90 \%$ in 2000 based on upper poverty line. During this period, the compound poverty reduction rate per year is recorded at $1.8 \%$.

When most of the countries faced the effects of global economic crises, Bangladesh has acquired higher GDP growth rates compared to the previous years. In 2012-13, the GDP of Bangladesh reached 6\%, which is close to the developing countries (China and India are estimated to have rates of $8.8 \%$ and $7.3 \%$, respectively). The real GDP of Bangladesh from 2010 to 2017 is given in table 2.

Table no. 2. Real GDP growth rate of Bangladesh in percent

\begin{tabular}{|l|l|l|l|l|l|l|l|l|}
\hline Bangladesh & 2010 & 2011 & 2012 & 2013 & 2014 & 2015 & 2016 & 2017 \\
\hline $\begin{array}{l}\text { Real GDP growth rate } \\
(\%)\end{array}$ & 6 & 6.5 & 6.1 & 6.6 & 6.3 & 6.9 & 7.0 & 7.1 \\
\hline
\end{tabular}

The foreign currency reserves of Bangladesh have increased to $\$ 10.19$ billion in April 2012 after the first instalment of the IMF loan was disbursed under the Extended Credit Facility (ECF) arrangement. In 2016, the foreign currency reserves reached to $\$ 29$ billion and expected to increase \$31 billion by the end of 2018 .

On the other hand, the tax revenues exceeded a record about $10 \%$ of GDP in FY 2011. The Government's loan became more than doubled over the 2010 to 2011, leading to concerns of higher inflation in the economy, and due to a large spending on subsidy in the power and energy sectors, and on social safety net coverage. The loans to the Government from the commercial banks and central bank have reached about \$1.96 billion in FY 2011. From the commercial banks alone, the Government 

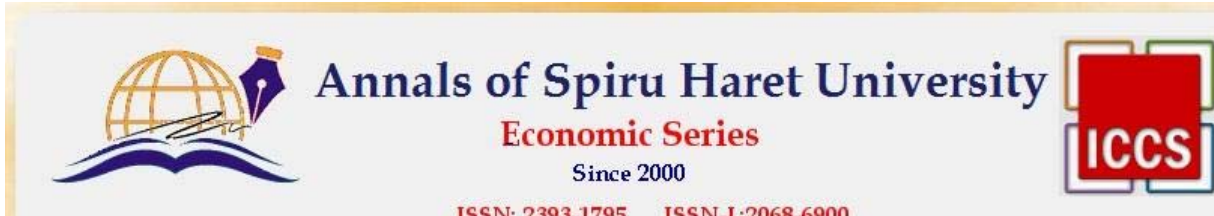

ISSN: $2393-1795 \quad$ ISSN-L-2068-6900

Issue 1/2018

has borrowed around $\$ 1.3$ billion. The Government borrowing created various problems for the economy as follows [Mohajan, 2013a]:

- The increased borrowing may force up interest rates and crowd out private sector investment in the country.

- If this borrowing trend continues, the Government may need to increase the tax burden on the long term.

- The increase in national debt would mean that the annual interest payments will rise.

\section{Recommendations and suggestions}

Rice is staple food of Bangladesh. The GoB should take various steps to produce more rice to feed more than 160 million people. The Government also needs to store sufficient foods to face natural calamities. Production of new varieties of genetically modified crops should be produced to increase production of food. The poor spend more than half of their earnings for food. Sometimes they only can buy starch rich foods, but cannot buy enough protein rich foods, such as meat, fish, milk etc. due to higher cost of these items. Hence, the Government must take necessary steps to produce enough dairy, poultry, and hatchery foods to fulfil the requirements of protein to all the citizens. The Government also increases its budget for research in agriculture, which will lead to the long-term food insecurity of the country. The subsidies in food must be decreased gradually for the long-term benefit of the agriculture sector. The dependency on food aid must be decreased to make the country self sufficient in food in the future. Then the country can take steps to export food by producing more.

The country is burden with large population, and most of the population is illiterate and unskilled. Every year, the Government has to spend more money to feed these people. As a result, other economic and non-economic development programs are not running in full swaying. The GoB should stress on family planning to decrease the rate of population escalation. The child marriage is a social fever in Bangladesh. The Government and NGOs must be active to stop child marriage in every stage of the society. The Government can stop it by strictly applying the marriage rules in the society. The Government should take necessary steps of safely return of the Rohinga refugees to their own motherland.

The Government also increases budget for education, as the educated population will help the country progress economically. It also takes various steps for free medical facilities to keep the nation healthy. Immunization projects are 


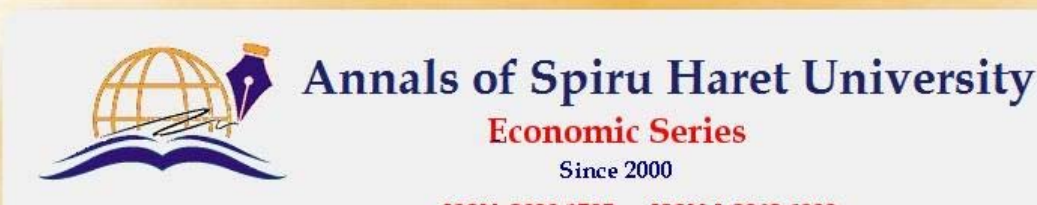

ISSN: 2393-1795 ISSN-L:2068-6900

\section{Issue 1/2018}

worth of praising in Bangladesh. Government should spent more in health and nutrition projects, especially for mother and child nutrition.

Political unrest is a common problem of the country. The Government and the citizens must be concerned with decreasing the political instability in the country. Political unrest reduces foreign direct investment, and destructs both public and private assets. As a result, the poor suffer much from political unrest. Government must strictly eradicate corruptions from the society in order to develop the country economically.

\section{Conclusions}

In this study, we have highlighted the need to support food production in order to reduce the poverty of the country. Bangladesh is one of the densely populated developing countries of the world. The budget for family planning must be increased to control population growth. The application of laws against child marriage must be strict in order to build a healthy and safety mother community. The GoB should apply the modern agriculture technologies to develop the country's agriculture. Natural calamities are also obstacles of the economic development, and Government should increase employment programs instead of offering relief aids for the natural disaster affected people. The Government must reduce the political instability and increase continuous energy supply. The prolonged food price inflation has to be controlled for the food security of those in need. The Government must increase the budget for research and development projects in the food and agriculture sector. Irrigation system must be increased to produce more food during the dry season and the electricity supply must be increased in the irrigation sector. The Government should take steps to distribute solar pumps with low prices for irrigation. Modern and new technologies must apply for storing rainwater for the dry season. New and genetically modified crop production must be increased to make country self sufficient in the food sector.

\section{References}

1. Ahmed, I., Farah, Q. F., Salahuddin, N. \& Chowdhury, M. I., Inflationary Trend in Bangladesh and Impact on High Food Commodity Prices, Unnayan Onneshan - The Innovators, Economic Policy Unit (EPU) Bangladesh (2009).

2. Ahmed, M. R., Rahaman, K. R., Kok, A. \& Hassan, Q. K., "Remote Sensing-Based Quantification of the Impact of Flash Flooding on the Rice Production: A Case Study over Northeastern Bangladesh.” Sensors, 17(10), E2347, (2017): 1-14. 
3. Agribusiness for Trade Competitiveness, Study on the Roles and Opportunities for Private Sector in Agro-food Processing Industry of Bangladesh (Katalyst, Swiss Foundation for Technical Cooperation, 2016).

4. Alam, S., Implementation of the $7^{\text {th }}$ FYP and the SDGs: Challenges and way forward. Government of the Peoples’ Republic of Bangladesh Ministry of Planning Planning Commission General Economics Division (GED). Bangladesh Development Forum 2018.

5. Basak, J. K., Ali, M. A., Islam, N. \& Rashid, A., "Assessment of the Effect of Climate Change on Boro Rice Production in Bangladesh Using DSSAT Model.” Journal of Civil Engineering (IEB), 38(2), (2010): 95-108.

6. BBS, Yearbook of Agricultural Statistics (Statistics and Informatics Division (SID), Ministry of Planning Government of the People's Republic of Bangladesh, 2011).

7. BBS, Yearbook of Agricultural Statistics (Statistics and Informatics Division (SID), Ministry of Planning Government of the People's Republic of Bangladesh, 2013).

8. BBS, Yearbook of Agricultural Statistics (Statistics and Informatics Division (SID), Ministry of Planning Government of the People's Republic of Bangladesh, 2017).

9. BBS, Yearbook of Agricultural Statistics (Statistics and Informatics Division (SID), Ministry of Planning Government of the People's Republic of Bangladesh, 2018).

10. BER, Bangladesh Economic Review, BER: Ministry of Finance (Bangladesh, 2008).

11. BDF, Building Resilience in Agriculture and Extreme Climate Condition. Bangladesh Development Forum 2018.

12. Bangladesh Economy, Bangladesh Economy in FY2016-17. Interim Review of Macroeconomic Performance. Centre for Policy Dialogue (CPD). Bangladesh, 2017.

13. Bangladesh Economic Update, Food Prices and Inflation Trajectory, Economic Policy Unit, Unnayan Onneshan (The Innovators), 2(1), (2011): 1-12.

14. Chowdhury, M. K. I., Rumi, S. F. \& Rahman, M. M., "Efficiency of Rice Farms during Boro Period in Bangladesh: An Econometric Approach.” Global Journal of Management and Business Research, 13(6), (2013): 33-44.

15. Country Profile, People’s Republic of Bangladesh, country profile 2013.

16. Country Profile, People’s Republic of Bangladesh, country profile 2016.

17. Country Profile, People’s Republic of Bangladesh, country profile 2018.

18. Dascalu, D., "Public Debt Analysis Based on Sustainability Indicators.” Annals of Spiru Haret University. Economic Series, 16(3), (2016): 79-92.

19. Dasgupta, S., Hossain, M. M. \& Wheeler, D., "Climate Change, Salinization and HighYield Rice Production in Coastal Bangladesh.” Agricultural and Resource Economics Review, (2017): 1-24.

20. FAO, Towards Sustainable Agriculture and Improved Food Security \& Nutrition. CPF 2014-2018 (Bangladesh Country Programming Framework. Food and Agriculture Organization of the United Nations, 2014). 
Issue 1/2018

21. FAO, Country Fact Sheet on Food and Agriculture Policy Trends. Socio-economic Context and Role of Agriculture (Food and Agriculture Policy Decision Analysis (FAPDA), 2016).

22.FAO, The Future of Food and Agriculture: Trends and Challenges (Food and Agriculture Organization of the United Nations, Rome, 2017).

23. Farzana, F. D., Rahman, A. S., Sultana, S., Raihan, M. J., Haque, M. A., Waid, J. L., Choudhury, N. \& Ahmed, T., "Coping Strategies Related to Food Insecurity at the Household Level in Bangladesh.” PLoS ONE, 12(4), e0171411, (2017): 1-17.

24. FPMU, "Bangladesh Food Situation Report." FPMU, Ministry of Food, 106, (2016): 16.

25. Gurgu, E. \& Zorzoliu, R., "Romania's Main Role in the Current Global Economic Context.” Annals of Spiru Haret University. Economic Series, 7(3), (2016): 19-36.

26. Gurung, K., Bhandari, H., \& Paris, T., "Transformation from Rice Farming to Commercial Aquaculture in Bangladesh: Implications for Gender, Food Security, and Livelihood.” Gender, Technology and Development, SAGE Publications, 20(1), (2016): 49-80.

27. Hasan, K., Habib, A., Abdullah, M., Bhattacharjee, D. \& Afrad, S. I., "Impact of Alternate Wetting and Drying Technique on Rice Production in the Drought Prone Areas of Bangladesh.” Indian Research Journal of Extension Education, 16(1), (2016): 39-48.

28. Household Income and Expenditure Survey, HIES, Preliminary Report on Household Income \& Expenditure Survey (Statistics Division, Ministry of Planning. The Government of the People's Republic of Bangladesh, 2010).

29. HIES, Preliminary Report on Household Income \& Expenditure Survey (Statistics Division. Ministry of Planning, The Government of the People's Republic of Bangladesh, 2016).

30. Islam, M. Z., Begum, R., Sharmin, S. \& Khan, A., "Profitability and Productivity of Rice Production in Selected Coastal Area of Satkhira District in Bangladesh." International Journal of Business, Management and Social Research, 3(1), (2017): 148-153.

31. Khuda, B. E., "Social Safety Net Programmes in Bangladesh: A Review.” Bangladesh Development Studies, XXXIV(2), (2011): 87-108.

32. Lagos, J. E. \& Hossain, T., Bangladesh Grain and Feed Annual (Global Agricultural Information Network - USDA Foreign Agricultural Service, 2016).

33. Mamun, A. H. M. M., Ghosh, B. C. \& Islam, S. M. R., "Climate Change and Rice Yield in Bangladesh: A Micro Regional Analysis of Time Series Data.” International Journal of Scientific and Research Publications, 5(2), (2015): 1-8.

34. Ministry of Food of Bangladesh, "National Food Policy Plan of Action and Country Investment Plan.” Monitoring Report 2015 (Ministry of Food Division, Bangladesh, 2015). 


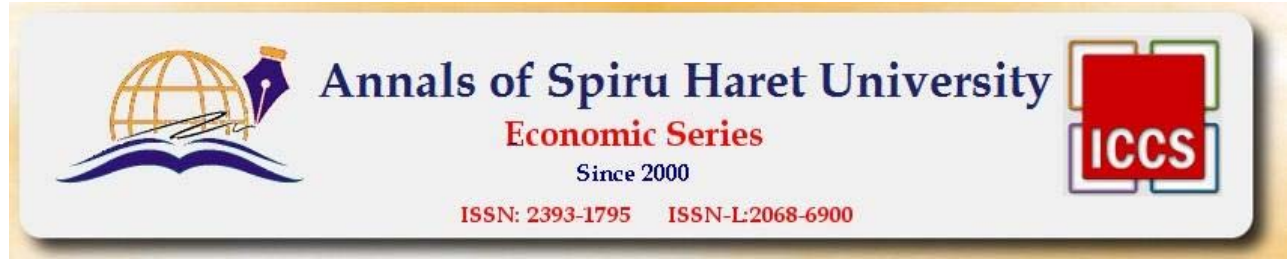

Issue 1/2018

35. Ministry of Food of Bangladesh, Monitoring Report 2018 (Ministry of Food Division, Bangladesh, 2018).

36. Mohajan, H. K., “Economic Development of Bangladesh.” Journal of Business Management and Administration, 1(4), (2013a): 41-48.

37. Mohajan, H. K., "Food and Nutrition of Bangladesh.” Peak Journal of Food Science and Technology, 2(1), (2013b):1-17.

38. Mohajan, H. K., History of Rakhine State and the Origin of Rohingya Muslims. Unpublished Manuscript, 2018.

39. Nagothu, U. S., Nemes, A., Biswas, J. C. \& Sarker, M. H., Climate Change Impacts, Vulnerability and Adaptation: Sustaining Rice Production in Bangladesh. Bioforsk Report (Norwegian Institute for Agricultural and Environmental Research, 2014).

40. Rahman, A., Mamun, A., Afrooz, N., Howlader, S. \& Qudrot-E-Khuda, A.B.M., "Rice Processing Industry of Bangladesh.” Emerging Credit Rating Limited Department of Research Industry Analysis Series (2017).

41. Rahman, N. M. F., Hasan, M. M., Hossain, M. I., Baten, M. A., Hosen, S., Ali, M. A. \& Kabir, M. S., "Forecasting Aus Rice Area and Production in Bangladesh Using BoxJenkins Approach,” Bangladesh Rice Journal, 20(1), (2016): 1-10.

42. Rahman, T. R., "Role of Agriculture in Bangladesh Economy: Uncovering the Problems and Challenges,” International Journal of Business and Management Invention, 6(7), (2017): 36-46.

43. Sen, A., "What’s happening in Bangladesh?” The Lancet, (2013): 1966-1968.

44. Sultana, A., "Rice Marketing in Bangladesh: From the Perspective of Village Study at Cox's Bazar District.” African Journal of Agricultural Research, 7(45), (2012): 5995-6004.

45. Talukder, D. \& Chile, L., "Characteristics of Rice Cultivation and Rural Rice Market in Bangladesh: Evidence from a Survey.” Agricultural Economics Review, 15(2), (2015): 68-84.

46. Tiongco, M. \& Hossain, M., “Adoption of Modern Varieties and Rice Varietal Diversity on Household Farms in Bangladesh.” HarvestPlus Working Paper No. 22. Paper Presented at the Workshop Adoption and Diffusion of Modern Rice Varieties in Bangladesh and Eastern India, Held October 3-4, 2009, BRAC, Dhaka, Bangladesh, 2015.

47. The Daily Star, The Daily Newspaper of Bangladesh, 30 October 2009. 
